\title{
Growth of the marine microalga Tetraselmis suecica in batch cultures with different salinities and nutrient concentrations
}

Fabregas, J., Abalde, J., Herrero, C., Cabezas, B., Veiga, M.

Departamento de Microbiologia, Facultades de Farmacia y Medicina, Universidad de Santiago, Santiago de Compostela, Spain

Aquaculture

Volume 42, Issue 3-4, 1 December 1984, Pages 207-215

ISSN: 00448486

DOI: 10.1016/0044-8486(84)90101-7

\section{Abstract}

The marine microalga Tetraselmis suecica is known for its ability to tolerate a wide range of salt concentrations. Cultures were grown under 48 different nutrient concentration-salinity conditions, ranging from 2 to $64 \mathrm{mM} \mathrm{NaNO}_{3}$ and from 0 to $35 \% \mathrm{~S}$. Salinity was more important for the growth rate of the microalgae when it was related to the nutrient concentration in the culture medium. Optimal growth conditions were between 25 and $35 \%$ salinity and nutrient concentrations of 2, 4 and $8 \mathrm{mM}$ of $\mathrm{NaNO}_{3}$, resulting in 0.55 doublings/day and a maximum cellular density of $1.3 \times 10^{6} \mathrm{cell} / \mathrm{s} / \mathrm{ml}$. Variations in salinity and in nutrient concentration had a greater effect on the final biomass than on the growth velocity. The total protein of the culture and protein per cell increased when the salinity increased for a given nutrient concentration. The total protein of the cultures decreased when the nutrient concentration increased for a given salinity. Protein per cell decreased with increasing salinity up to $20 \%$ but from this point of the process was reversed. The nitrateprotein transformation rate increased with the salinity and decreased with increasing nutrient concentrations. The maximum rate was $64 \%$. 


\section{Introduction}

Microorganisms are potentially useful as food for human consumption, in the production of chemicals, in aquaculture and in the bioconversion of solar energy (Kharatyan, 1978; Goldman, 1979). The marine microalga Tetraselmis suecica (Prasinophyceae) is at present widely used in aquaculture (Walne, 1974; Bayne, 1976; Laing and Utting, 1980). If its growth response to a wide range of nutrient concentrations and salinity conditions in batch cultures were known we could establish some of the para-meters for a mass production which would enable us to obtain maximum growth velocity, cellular density and protein concentration.

Several studies have revealed significant differences in the ability of various species or classes of microalgae to utilize nutrients at low concentrations. Such studies have provided much useful information on the adaptabilities of marine microalgae and have significant implications regarding competition between species under various conditions of limiting nutrients (Laws and Bannister, 1980). There is no doubt that many algae grow over a wide range of combinations of temperature, light and nutrient concentrations and yet maintain their elemental composition within more or less narrow limits. It is therefore clear that microalgae have mechanisms for regulating the uptake of each element and that these mechanisms serve to maintain composition and to achieve balanced growth (Stross and Pemrick, 1974).

\section{Materials and methods}

The microalga used was Tetraselmis suecica, isolated from the waters of Ria de Arosa (Fabregas, 1982). It was cultured in seawater filtered through a $0.45 \mu$ Millipore filter, autoclaved at $120^{\circ} \mathrm{C}$ for 20 min and enriched with $\mathrm{NaNO}_{3}, 2 \mathrm{mM} ; \mathrm{NaH}_{2} \mathrm{PO}_{4}, 100 \mu \mathrm{M} ; \mathrm{ZnCl}_{2}$, $1 \mu \mathrm{M}, \mathrm{MnCl}_{2}, 1 \mu \mathrm{M} ; \mathrm{Na}_{2} \mathrm{MoO}_{4}, 1 \mu \mathrm{M} ; \mathrm{CoCl}_{2}, 0.1 \mu \mathrm{M} ; \mathrm{CuSO}_{4}, 0.1 \mu \mathrm{M}$; ferric citrate, $20 \mu \mathrm{M}$; thiamine,35 pg/l; biotin, 5 pg/l; B12 , 3pg/l; EDTA, $26.4 \mu M$; TRIS-HCl, 15 mM; pH 7.6.

We used salinities of $35,30,25,20,15,10,5$ and $0 \% 0$. The salinity of the seawater $(35 \% 0)$ was reduced by the addition of appropriate volumes of fresh distilled water prior to medium preparation.

The first nutrient concentration utilized was the one whose composition is given above and which corresponds to $\mathrm{NaNNO}_{3}, 2 \mathrm{mM}$. From this we followed a geometrical progression, using concentrations corresponding to $4,8,16,32$ and $64 \mathrm{mM}$ of $\mathrm{NaNO}_{3}$. Nutrient concentrations are expressed as $\mathrm{NaNO}_{3}$ concentrations, but refer to the whole medium.

Cultures were carried out in Kimax screw-capped test tubes $(15 \times 2.5 \mathrm{~cm})$ with $40 \mathrm{ml}$ of medium. All cultures were maintained in a controlled environment incubator (New Brunswick) at $15^{\circ} \mathrm{C}$ and 3900 lux light from fluorescent lamps (Phillips TL 20 W/55). A 12 : 12 dark: light 
regimewas maintained in order to obtain synchronous cultures. An inoculum of $1 \times 10^{4}$ logarithmic phase cells $/ \mathrm{ml}$ was used.

Optical density (OD ) of the cultures was determined by using a Coleman II 6/20 spectrophotometer reading at $530 \mathrm{~nm}$. Protein was measured in the stationary phase by the dye-binding method (Bradford, 1976). Cellular density was determined by counting culture aliquots in a Thoma chamber.

Stationary phases, corresponding to maximum biomass production, were compared by an overall multivariate one-way analysis of variance (ANOV A), and logarithmic phases, that indicate the growth velocity of the cultures, were compared by a one-way analysis of covariance (ANCOVA).

\section{Results and discussion}

We plotted optical density against time and against salinity for each nutrient concentration, obtaining three-dimensional figures (Fig. 1). Statistical treatment of these figures is represented in Table 1.
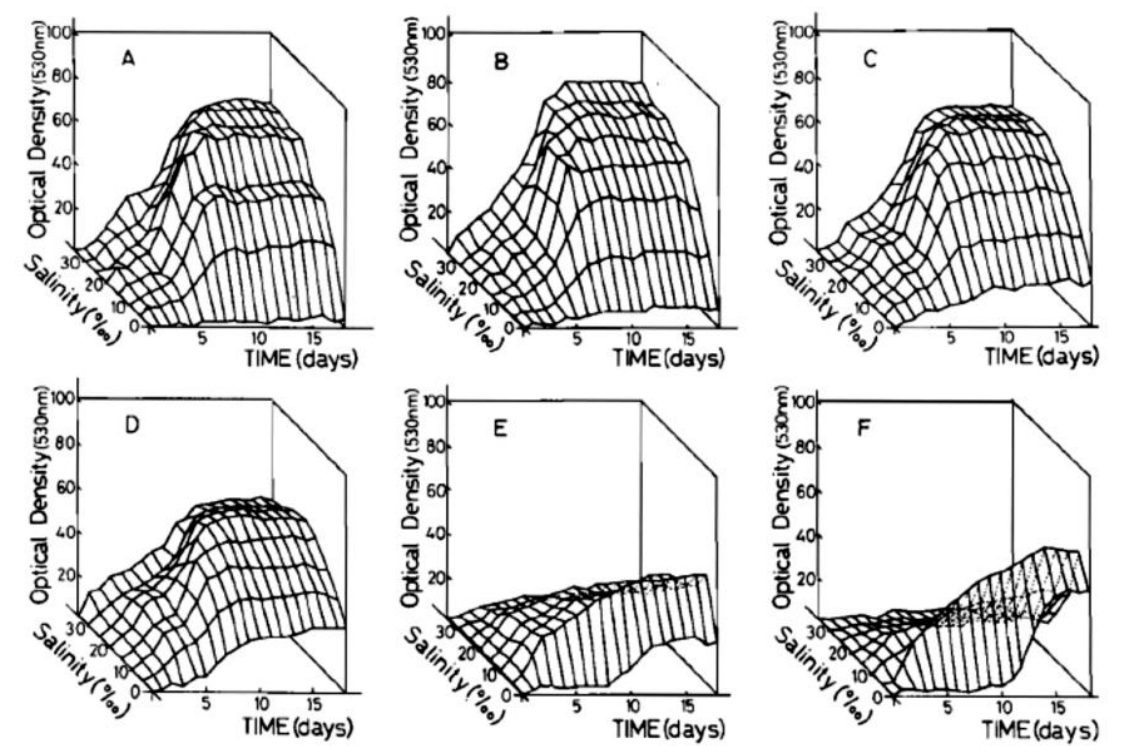

Fig. 1. Growth of T. suecica at different salinities and nutrient concentrations, expressed as NaNO, concentrations. OD at $530 \mathrm{~nm}$ is represented as (1-T) values. (A) Nutrient concentration $2 \mathrm{mM} \mathrm{NaNO}$; (B) $4 \mathrm{mM}$; (C) $8 \mathrm{mM}$; (D) $16 \mathrm{mM}$; (E) $32 \mathrm{mM}$ and (F) $64 \mathrm{mM}$.

It is generally accepted that a relation exists between optical density and cellular density (Lyon and Woo, 1980). In our experiments the relation between OD measured at $530 \mathrm{~nm}$ in screw-capped test tubes $\left(2.5 \mathrm{~cm}\right.$ light run), and cellular density fitted a power curve $y=a x^{b}$ with acorrelation coefficient of 0.99 . This relation was calculated for the entire culture period, and the values calculated for the constants were $y=0.98 x^{0.91}$. Nevertheless, a change in OD 
values does not always involve a change in the cellular density determined by counting, and this occurred with $0 \% 0$ salinity and with nutrient concentrations higher than $16 \mathrm{mM} \mathrm{NaNO}_{3}$.

Salinity is known to interact with other variables (Terlizzi and Karlander, 1980).

\section{TABLE I}

\begin{tabular}{|c|c|c|c|}
\hline $\begin{array}{l}\text { Nutrient } \\
\text { concentration }{ }^{a} \\
(\mathrm{~m} M)\end{array}$ & $\begin{array}{l}\text { Growth } \\
\text { phase }\end{array}$ & $P$ & Salinities $(\%)$ \\
\hline 2 & $\begin{array}{l}\text { Stationary } \\
\text { Logarithmic }^{\mathrm{b}}\end{array}$ & $\begin{array}{l}0.01 \\
0.05\end{array}$ & $\begin{array}{l}35=30=25=20>15=10>5>0 \\
35=30=25=20=15=10=5>0\end{array}$ \\
\hline 4 & $\begin{array}{l}\text { Stationary } \\
\text { Logarithmic }\end{array}$ & $\begin{array}{l}0.01 \\
0.05\end{array}$ & $\begin{array}{l}35>30=25>20>15>10>5>0 \\
35=30=25=20=15=10>5>0\end{array}$ \\
\hline 8 & $\begin{array}{l}\text { Stationary } \\
\text { Logarithmic }\end{array}$ & $\begin{array}{l}0.01 \\
0.05\end{array}$ & $\begin{array}{l}35=30=25>20>15>10>5>0 \\
35=30=25=20=15=10=5>0\end{array}$ \\
\hline 16 & $\begin{array}{l}\text { Stationary } \\
\text { Logarithmic }\end{array}$ & $\begin{array}{l}0.01 \\
0.05\end{array}$ & $\begin{array}{l}35=30=25=20>15>10>5>0 \\
35=30=25=20=15=10>5>0\end{array}$ \\
\hline 32 & $\begin{array}{l}\text { Stationary } \\
\text { Logarithmic }\end{array}$ & $\begin{array}{l}0.01 \\
0.05\end{array}$ & $\begin{array}{l}35<30<25<20<15<10<5>0 \\
35<30=25=20=15=10=5>0\end{array}$ \\
\hline 64 & $\begin{array}{l}\text { Stationary } \\
\text { Logarithmic }\end{array}$ & $\begin{array}{l}0.01 \\
0.05\end{array}$ & $\begin{array}{l}35<30<25<20<15<10<5>0 \\
35<30<25=20<15=10=5>0\end{array}$ \\
\hline
\end{tabular}

\footnotetext{
${ }^{\text {a}}$ Expressed as $\mathrm{NaNO}_{3}$ concentration.

b One-way analysis of variance.

${ }^{c}$ One-way analysis of covariance.
}

Marine unicellular algae are generally considered to be tolerant of and adaptable to a wide range of salinities (McLachlan, 1961). The marine microalgae T. suecica tolerates a wide range of salt concentrations. This is also the case for the green alga Dunaliella which is able to survive in a wide range of salt concentrations by changing the internal concentrations of glycerol and so adjusting its osmotic potential (Ben-Amotz and Avron, 1973; 1978).

Optimal growth conditions for obtaining a maximum cellular density in the stationary phase were $25-35 \%$ salinity and 2, 4 and $9 \mathrm{mM} \mathrm{NaNO}_{3}$ (Fig. 1A, B, C). Ranges of optimal salinity for growth in media prepared from artificial seawater were found to be $15-25 \%$ for Isochrysis and $25-30 \%$ for Tetraselmis (Laing and Utting, 1980).

Cellular densities of about $1.3 \times 10^{6} \mathrm{~T}$. suecica cells $/ \mathrm{ml}$ were obtained in the optimal salinity range. Below $25 \%$, cellular density decreased proportionally to salinity. This relation occurred with nutrient concentrations up to $16 \mathrm{mM} \mathrm{NaNO}_{3}$. Higher concentrations reversed the process (Fig. IE, F). It may be supposed that a more exact adjustment of the ionic composition of the culture medium would allow better cellular metabolism, providing 
improved nutrient utilization and greater growth at low salinities and high nutrient concentrations.

Salinity and nutrient concentrations have little effect on the growth velocity in comparison with the biomass production reached in the stationary phase. The maximum growth velocity of $T$. suecica was practically the same in a wide range of salinities, with 0.55 doublings/day. A significant decrease appeared at 0 and $5 \%$ o and with 2 to $16 \mathrm{mM}$ of $\mathrm{NaNO}_{3} \mathrm{~A}$ change in the growth velocity occurred at higher nutrient concentrations and was not proportionally related to salinity variations.

Samples for protein measurement were always collected at the same time because protein concentration varies depending on the moment in the light period at which the sample is taken (Van Liere et al., 1979). Nutrient concentrations influenced the protein content of $T$. suecica cultures. Other authors have pointed out that nutrient supply influences the chlorophyll a, carbohydrate and protein content of unialgal cultures (Myklestad, 1974).

When the nutrient concentration increased the total protein content of the cultures tended to diminish (Fig. 2). Protein/cell ratio also tended to diminish from 0 to $20 \% 0$ of salinity, but the process was reversed at higher salinities (Fig. 3), for each nutrient concentration. When the salinity increased the total protein content of the cultures and the protein per cell tended to increase.

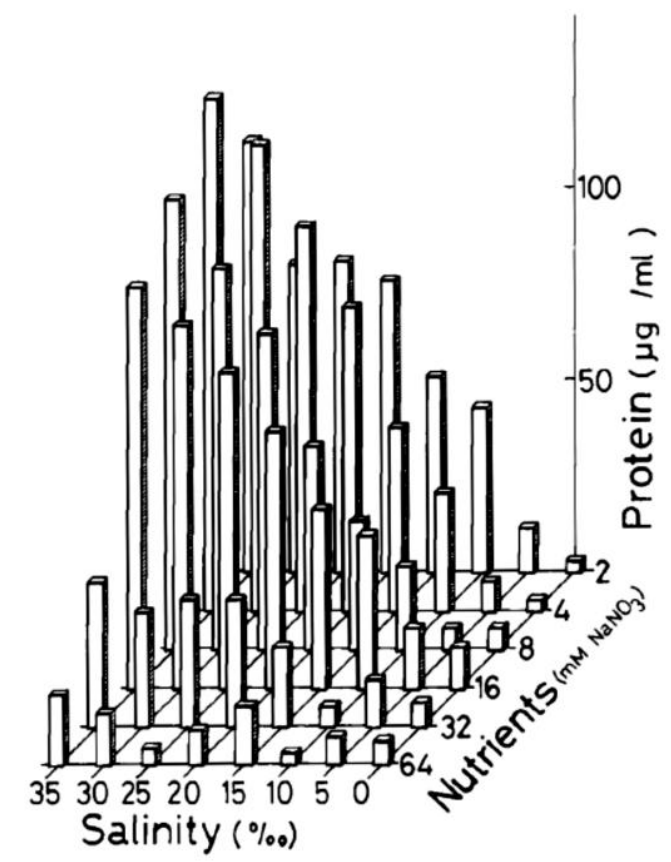

Fig. 2. Protein concentration in cultures of $T$. suecica at different salinities and nutrient concentrations. 
Changes in the protein content are not necessarily indicative of cellular density changes because the biochemical composition of $T$. suecica may change within more or less narrow limits depending on environmental conditions.

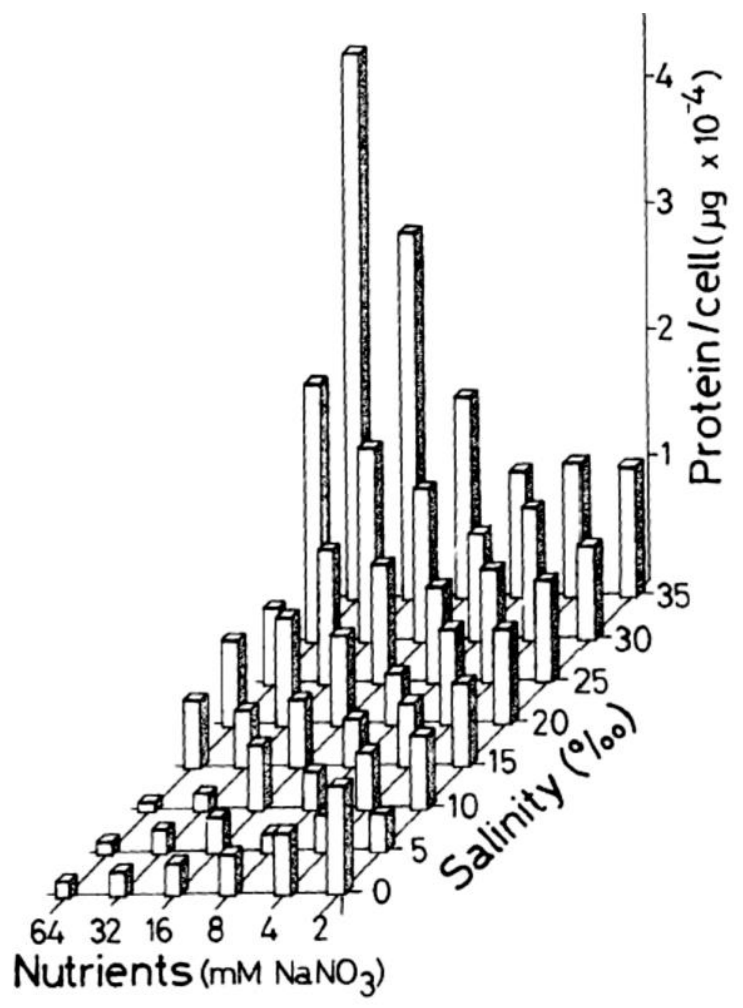

Fig. 3. Protein/cell ratio in cultures of $T$. suecica at different salinities and nutrient concentrations.

We established efficiency as the ratio between nitrogen added in nitrate form to the culture medium and the protein nitrogen produced per culture. The efficiency increased when salinity increased and decreased when nutrient concentrations increased, giving values about zero with high nutrient concentrations (Fig. 4). The carbon source was possibly the limiting factor which decreased efficiency proportionally to nutrient concentrations.

In batch cultures of microalgae without aeration and with an excess of nutrients, two growthlimiting factors are $\mathrm{CO} 2$ and $\mathrm{pH}$, and these may or may not be related. Furthermore, this excess of nutrients can introduce other limiting factors such as toxicity produced by TRIS concentrations (Guillard and Ryther, 1962), osmotic pressure and the lack of adjustment in ionic relations. 


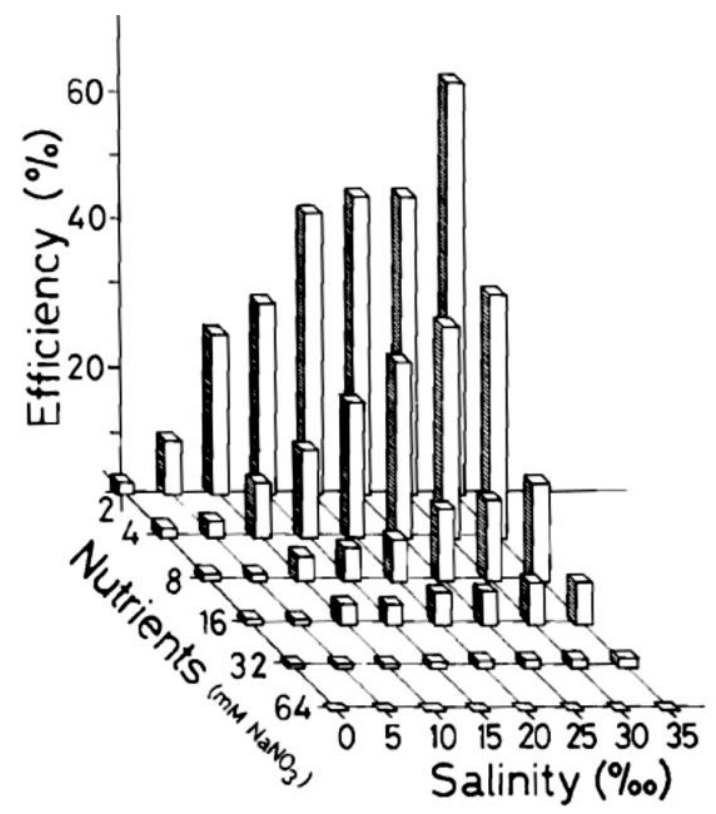

Fig. 4. Nitrate-N/protein-N transformation rate (efficiency) in cultures of $T$. suecica at different salinities and nutrient concentrations.

With regard to $\mathrm{pH}$ as the limiting factor, the culture medium used was buffered with TRIS (Guillard and Ryther, 1962; McLachlan and Gorham, 1962; Pintner and Provasoli, 1958; Sorge and McLaughlin, 1970) which maintained the $\mathrm{pH}$ within the optimum range for growth of $T$. suecica (Fig. 5).

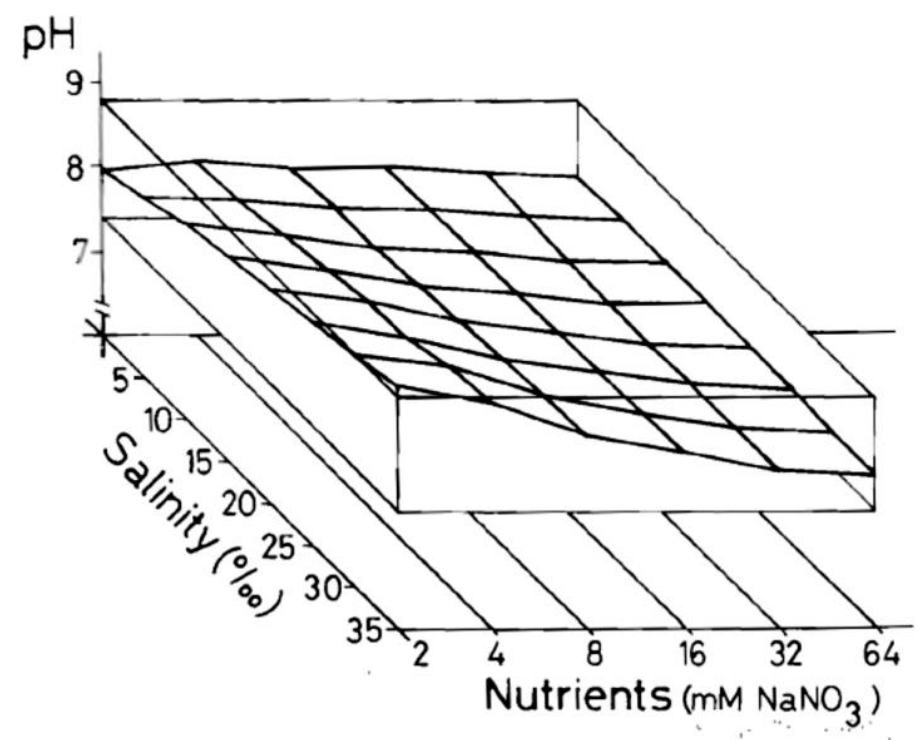

Fig. 5. pH values in cultures of $T$. suecica at different salinities and nutrient concentrations.

We showed that the carbon source was the limiting factor because an increase in the nutrient concentration did not produce an increase in biomass production, but $\mathrm{CO}_{2}$ added to the cultures increased the final biomass production. If the cultures had been aerated, the final biomass production would have been greater because the atmospheric $\mathrm{CO}_{2}$ supply would have provided a carbon source. 


\section{References}

1. Bayne BL. The biology of mussel larvae. Marine Mussels: Their Ecology and Physiology 1976:81-120.

2. Ben-Amotz A, Avron M. The role of glycerol in the osmotic regulation of the halophilic alga dunaliella parva. Plant Physiol 1973;51:875-8.

3. Ben-Amotz A, Avron M. On the mechanism of osmoregulation in dunaliella. Energetics and Structure of Halophilic Microorganisms 1978:529-41.

4. Bradford MM. A rapid and sensitive method for the quantitation of microgram quantities of protein utilizing the principle of protein-dye binding. Anal Biochem 1976;72(1-2):248-54.

5. Fabregas J. Las microalgas marinas como eslabon de infraestructura en la microbiologia marina: Aislamiento, caracterization, ciclo celular, interacciones y aprovechamiento tecnologico. Ph.D.Thesis 1982:467.

6. Goldman JC. Outdoor algal mass cultures. I. applications. Water Res 1979;13(1):1-19.

7. Guillard R R, Ryther J H. Studies of marine planktonic diatoms. I. cyclotella nana hustedt, and detonula confervacea (cleve) gran. Can J Microbiol 1962;8:229-39.

8. Kharatyan SG. Microbes as food for humans. Annu Rev Microbiol 1978;32:301-27.

9. Laing I, Utting S. The influence of salinity on the production of two commercially important unicellular marine algae. Aquaculture 1980;21:79-86.

10. Laws EA, Bannister TT. Nutrient- and light-limited growth of thalassiosira fluviatilis in continuous culture, with implications for phytoplankton growth in the ocean. Limnol Oceanogr 1980;25(3):457-73.

11. Lyon HW, Woo CS. Accelerated uptake response of the green alga, chlorella vulgaris, to high levels of phosphorus in mississippi river water. Science of the Total Environment, the $1980 ; 14(3): 279-85$.

12. McLachlan J. The effect of salinity on growth and chlorophyll content in representative classes of unicellular marine algae. Can J Microbiol 1961;7(3):399-406.

13. McLachlan J, Gorham PR. Effects of $\mathrm{pH}$ and nitrogen sources on growth of microcystis aeruginosa kütz. Can J Microbiol 1962;8:1-11.

14. Myklestad S. Production of carbohydrates by marine planktonic diatoms. I. comparison of nine different species in culture. J Exp Mar Biol Ecol 1974;15(3):261-74.

15. Pintner I J, Provasoli L. Artificial cultivation of a red-pigmented marine blue-green alga, phormidium persicinum. J Gen Microbiol 1958;18(1):190-7.

16. Sorge E, McLaughlin J. Physiological studies of algae isolated from a polluted biotope. Dev Ind Microbiol 1970;12:109-25. 
17. Stross R, Pemrick S. Nutrient uptake kinetics in phytoplankton: A basis for niche separation. J Phycol 1974;10:164-9.

18. Terlizzi D, Jr., Karlander E. Growth of a coccoid nonoplankter (eustigmatophyceae) from the chesapeake bay as influenced by light temperature salinity and nitrogen source in factorial combination. J Phycol 1980;16:364-8.

19. Van Liere L, Mur LR, Gibson CE, Herdman M. Growth and physiology of oscillatoria agardhii gomont cultivated in continuous culture with a light-dark cycle. Arch Microbiol 1979;123(3):315-8.

20. Walne PR. Culture of Bivalve Molluscs 1974. 